\title{
Gender Empowerment in South Korean Development: Lessons for Foreign $\mathrm{Aid}^{*}$
}

\author{
EUN MEE KIM ${ }^{* *}$ AND JAE EUN LeE ${ }^{* * *}$
}

\begin{abstract}
South Korea's rapid economic development in the 20th century had in its core women's employment in labor-intensive export industries. This paper examines South Korea's economic development through the lens of women's employment and gender empowerment. Although women's empowerment was not part of a goal of South Korea's development, large mobilization of women in the exporting light manufacturing sector eventually led to women's empowerment. Using OECD/DAC's guidelines on gender mainstreaming and gender equality, the paper examines how the South Korean experience can provide an alternative to women's empowerment in developing countries. We conclude that there has to be greater sensitivity to address gender-related issues including gender-mainstreaming and gender-sensitive budgets in order to help women attain economic as well as political empowerment in development cooperation.
\end{abstract}

Keyuonds: South Korea, ODA, Gender, Gender Equality, Women Empowerment, Gender Mainstreaming, Women's Employment, Women's Movements

Authors would like to express gratitude for comments and support from Dr. Pil Ho Kim (Post-Doctoral Fellow at the Institute for Development and Human Security at Ewha Womans University. Seoul,

Korea). and Gender Issues in East Asia" at Waseda University, Tokyo, Japan on December 4, 2010. This research was supported by the WCU (World Class University) program through the National Research Foundation of Korea funded by the Ministry of Education. Science and Technology of the Republic of Korca (Grant No.: R32-20077).

Dean and Professor, Graduate School of International Studies; Director, Institute for Development and Human Security, Ewha Womans University; Dachyun-dong 11-1, Seodaemun-gu, Seoul, 120-750. Korea; Tel: 82-2-3277-3669; E-mail: emkim@ewha.ac.kr

$\mathrm{Ph} . \mathrm{D}$. Candidate, Graduate School of International Studies, Ewha Womans University; Program Specialist, Organizing Office for the Fourth High Level Forum on Aid Effectiveness, Ministry of Foreign Affairs and Trade, Republic of Korea; \#406 Officia Bldg.. Sinmunro 1-ga, Jongno-gu, Korea: Tel: 82-2-2100-7702; E-mail: jaeeunlee@empal.com 


\section{INTRODUCTION}

O outh Korea's transformation from an agrarian and poverty-stricken country $\mathcal{O}$ in the early 1960 s to the $14^{\text {th }}$ largest economy in the world can provide a story of hope to many developing countries aspiring for poverty reduction and economic development. Over the period from the late 1940 s to 1960 s, South Korca has becn onc of the largest recipients of foreign aid in the world. According to the OECD statistics database, foreign assistance including grants and concessional loans into South Korea during the period 1945-1995 reached up to USD 12.78 billion.

South Korea has joined the OECD's Development Assistance Committee (DAC) as its $24^{\text {th }}$ member in 2010 , and has declared its aspirations to increase its volume of foreign aid, but more importantly to share its distinct experiences of development for countries under chronic poverty. South Korea's development experience has been celebrated for its rapid economic development, attainment of democracy and gender equality, and these achievements within the context of security tensions and conflict with North Korea. These three issues are very important for countries living in extreme poverty, since many often suffer the double or triple challenges of lack of development, lack of democracy, and international wars and civil wars (Sachs 2005; Sen 1999). The South Korean case can provide an alternative for aid-receiving developing countries.

The paper has two goals. The first is to examine South Korea's history of economic development through the lens of gender empowerment. South Korea's main engine of growth in the initial stage of economic development was exports from labor-intensive light manufacturing sector. And young women were the major labor force in South Korea's export oriented industrialization. This paper explores women's employment and women's empowerment as the two pillars of women's participation in economic development of South Korea.

The second goal of the paper is to transform the experiences of women's employment and empowerment in South Korea to a development cooperation strategy for women in developing countries in the $21^{\text {s }}$ century. Using OECD/DAC's guidelines on gender mainstreaming and gender equality, the paper examines whether the South Korean experience can provide an alternative to women's empowerment in developing countries.

\section{GENDER IN SOUTH KOREA'S ECONOMIC DEVELOPMEN'T}

\section{Employment of Women}

There have been lively debates over the key factors of South Korean economic development. Many studies emphasized the role of the developmental state in 
leading South Korea's development as different from other studies that focused on the market (Amsden 1989; Wade 1990; Woo 1991; Kim, E.M. 1997). The developmental state literature, which began with the seminal work by Chalmers Johnson to explain Japan's phenomenal economic development since the end of World War II, influenced the way South Korea's development experience was understood vis-à-vis other latecomers (Johnson 1982). Earlier studies on South Korca's development tended to focus on the export-oriented industrialization (EOI) strategy, market liberalization, and free trade policies as the important driving force for its rapid growth (Harvie and Lee 2003). Many studies in this school emphasized that export-led growth in South Korea depended on a set of policies, which provided a favorable environment for private businesses. The emphasis was on market-enhancing policies that allowed the market to play an active role with the state only playing a supporting role. However, there appears to be some consensus that the proactive and leading role of the developmental state is seen as a distinct element of South Korea's development.

There has not been much attention on gender in the analyses of South Korea's economic development. Nevertheless, it should be acknowledged that women played a key role in South Korea's EOI, especially in its initial take-off period, during which light manufacturing exports were the bread and butter of South Korea's export business (Koo 2001; Kim, S. 1997). As noted by many researchers, analyzing women's employment can be complex during periods of significant economic transitions in developing countries, and Sourh Korea is no exception (Goldin 1990). The process of industrialization brings about increased gender equality as women gain access to paid employment, leading to greater access to, and control over, resources. An export-oriented growth strategy is viewed to be particularly effective in improving women's relative economic status due to its dependence on low-wages of women workers (Tzannatos 1998).

However, there is also concern that women's low wages do not drastically improve women's status in society since they are paid so poorly vis-à-vis men for comparable work. Export-oriented growth in the 1960s and 1970s in South Korea was driven by massive recruitment of women as low-wage workers in labor-intensive manufacturing sectors, and this resulted in gender earning inequalities, which persisted into the $1980 \mathrm{~s}$ and 1990s, in spite of relative gains in education and labor-market experience (Seguino 2000). In addition, when the heavy and chemical industries developed from the 1970 s based primarily on male workers, women's relative pay and status worsened over time (Kim, S. 1997). In South Korea, state policy was instrumental in mobilizing young women's labor for export manufacturing (Berik 2006). Employment policies adopted by both the state and employers led to gender-segregated employment and lower pay for women industrial workers (Seguino 1997).

Moreover, South Korea's patriarchal culture hindered female promotion, and kept married women out of jobs during the earlier period of industrialization. 
Contradictions between traditional values-childbirth, rearing and homemaking as a woman's "proper role"-and women's participation in the economy continue to influence the complex relations among society, family and gender roles in South Korea (Turner and Monk-Turner 2007). Despite the equitable attainment of education, the economic participation rate for women remains lower than that of men (Turner and Monk-Turner 2007). Figure 1 shows the historical trend of economic participation by sex in South Korea. Although women's participation has improved significantly from $37 \%$ in 1963 to $49 \%$ in 2009 , it falls short of men's participation, which stood at $78.4 \%$ in 1963 and $72.9 \%$ in 2009 .

Figure 1. Economic Participation Rate by Sex in South Korea, 1963-2009

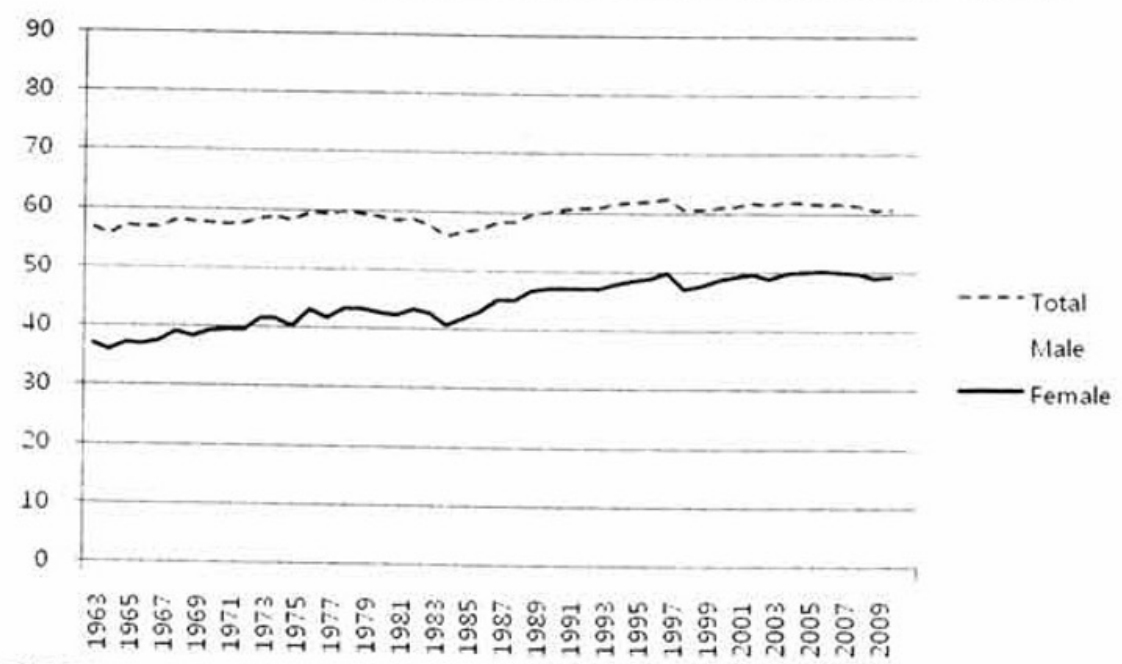

SOURCE: Korean Statistical Information Service Statistical Database.

Among the OECD member countries, South Korea's female labor participation rate is ranked $24^{\text {th }}$ in 2008 , faring far below the $14^{\text {th }}$ place the country is ranked in terms of GDP (see Figure 2). Thus, South Korea faces internal challenges to improve women's labor force participation to a level commensurate to its economic size.

\section{(1) Women's Employment in the Light Manufacturing Sector}

During the industrialization process, employment opportunities dramatically changed. Women's participation in the labor force increased, as the exportpromotion policy led to development of light and low technology industries for exports, which employed a large number of young, low-paid women (Berik 2006). Employment of women workers shows a common pattern in developing 
Figure 2. Labor force Participation Rate by Sex in The OeCD Countries, 2008

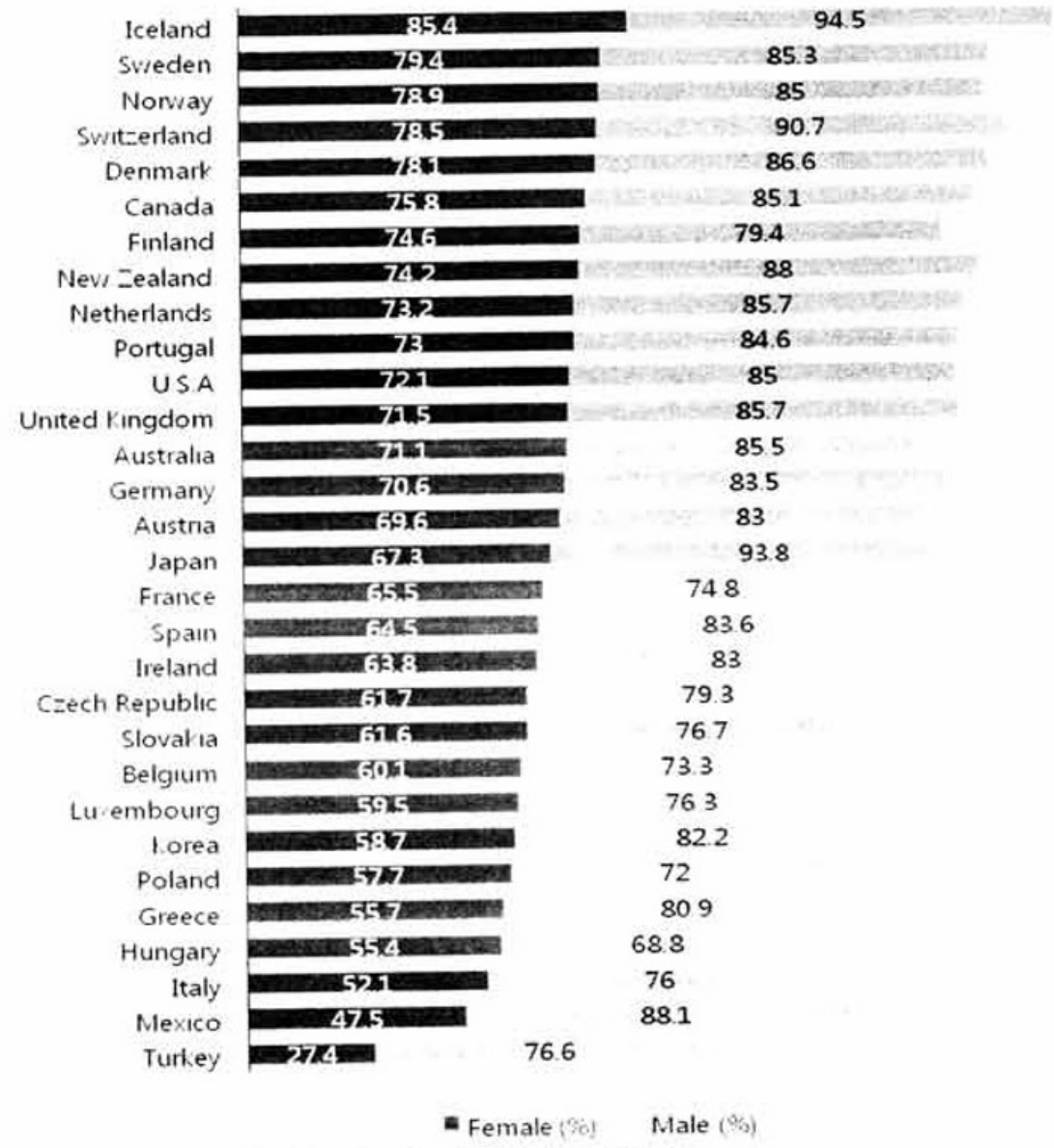

SOURCE: International Labor Organization Statistical Database.

countries in the industrialization process. The demand for female labor is highest in light and labor-intensive manufacturing sectors and lowest in heavy industries. This is due to the fact that labor costs take up the largest share of total production costs in light manufacturing sectors. And thus, in order to retain its cost-effectiveness, employers prefer hiring women, whose cost is lower but productivity is comparable to, or even higher than, those of male workers. Low economic cost, social prejudice against women, perceived unsuitability to dangerous work, perceived lower commitment to work and lower skill-level, all led to the concentration of women workers in light manufacturing sectors (Joekes 1995). The socially 
constructed constraints on women were partly based on periodic withdrawal of women from employment for childbirth and family care, which was misunderstood as their lack of commitment to work and/or low priority on work vis-à-vis domestic responsibilities.

\section{(2) Women's Employment and Exports}

In low-income countries, emphasis on trade liberalization and export-led industrialization had implications for women's economic activity. The large numbers of low-paid women workers, especially in export sectors, have contributed a great deal to the development of many newly and rapidly industrializing countries (Standing 1999). Table 1 shows how three out of the top four export industries, measured by foreign exchange earnings, were dominated by female employment at the height of South Korea's industrialization in 1987.

Table 1. Major Exports and female Employment, 1987

\begin{tabular}{lcc}
\hline \multicolumn{1}{c}{ Industry } & $\begin{array}{c}\text { Females as Percentage of Total } \\
\text { Industry Employees }\end{array}$ & Distribution of Female Workers \\
\hline Wearing Apparel & $72.9 \%$ & $16.1 \%$ \\
\hline Texriles & $62.5 \%$ & $20.9 \%$ \\
\hline Electronics & $52.6 \%$ & $19.1 \%$ \\
\hline Transport & $10.5 \%$ & 1.7 \\
\hline Source: Seguino $(1997.107)$.
\end{tabular}

In spite of the rising demand for female labor, women's relative wages did not improve significantly due to the EOI strategy based on price competitiveness (Seguino 1997). Figure 3 presents the wage gap by sex in many countries. In South Korea, gender wage gap remained wide compared to many other advanced industrialized nations, with women making only $57.2 \%$ of what men earned in 2007.

The South Korean developmental state intervened in the labor market in order to suppress labor costs and to raise productivity until the late 1980s when the democratization movement no longer tolerated such harsh labor policies of the state. In addition, South Korea's strong patriarchal norms based on Confucianism helped to justify greater oppression of female workers than male workers, which led to overall gender inequality including wage disparity (Berik 2007; Seguino 1997; Brinton et al. 1995).

The South Korean case reminds us that women's employment alone cannot change women's status in society through empowerment. Attention has to be paid to the underlying political, social and cultural structures that cause women to be paid less, segregated into low-paying jobs, and prevented from advancement. 
In the following section we will discuss how women's empowerment was attained in South Korea, which will be useful for other developing countries that face similar political, social and cultural constraints against women.

Figure 3. Wage Gap by Sex, Selected Countries, $2007^{\circ}$

\section{Ratio of Salary Disparity (Women to Men, \%)}

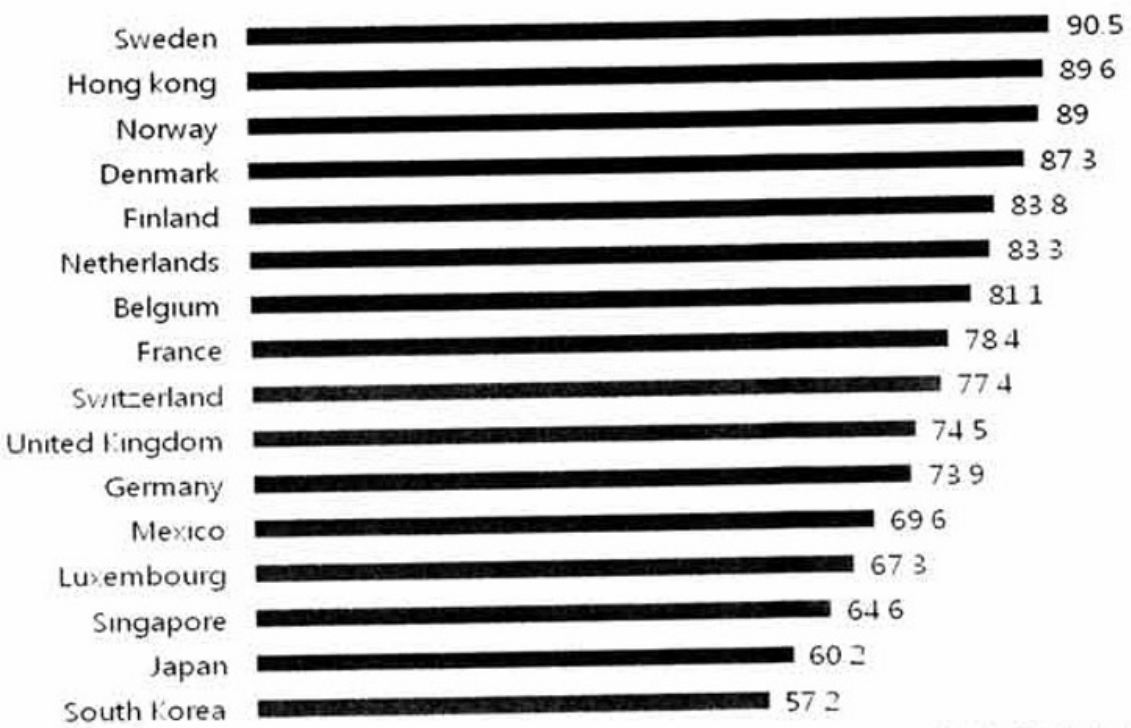

NOTE: The data from Belgium, Denmark. Germany, and Switzerland are in 2006; the Netherlands in 2005 and France in 2002.

SOURCE: International Labor Organization Statistical Database.

\section{Empouverment of Women}

\section{(1) Women's Movements}

In South Korea, women's employment in export sectors did not automatically lead to women's empowerment. But it provided a critical condition for women to engage in social movements, as it was dramatically shown in the textile industry in the 1970s. Hagen Koo (2001) writes about how women workers launched the independent labor movement in South Korea:

[S] everal major struggles to establish independent unions occurred in the 1970 s. Interestingly, the clear majority of these unionization struggles were led by women. Two of the best-known cases during this period occurred in 1972 at two large textile companies, Wonpoong and Dongil. At both 
companies, women workers staged a coup to take control of the company union. Unionists at Wonpoong built the strongest union established in the 1970 s, presenting an exemplary case of the independent union movement (Koo 2001, 73).

Other than the early labor movements led by women textile workers, the most prominent movement to enhance women's status was the call for legal change of the hoju (family-head) system since 1954. By law, the hoju system allows only a male member to be the legal head of family with all family members listed under the hoju. Under this patrilineal system, the status of each family member is defined in terms of his or her relationship to the boju. For example, when a husband/hoju dies, he is usually succeeded by his first-born son, not by his surviving wife. When a daughter gets married, her name is removed from her father's family register called bojeok and transferred to her husband's. Children are automatically added to the father's bojevk. Even when the mother retains sole legal custody over her children in a divorce, the children have to keep the father's family name and remain in his bojeok unless he gives permission to transfer. A family without a male heir naturally means the end of a lineage. More than 100 civic groups joined forces working for decades to change this Family Register Law, and finally in 2005 the South Korean National Assembly abolished the boju system. An appeal was made to resurrect the boju system, but was rejected by the highest court in South Korea, which clearly stated that the hoju system was unjust since it violated the right to gender equality (Constitutional Court of Korea 2005).

The civil society at large became much more actively engaged in protecting and promoting women's rights since the late 1980s (O Jang 2004). First, Korea Women's Hotline, which began in 1983 for a nonviolent world and equality of sexes, has grown to a nation-wide organization with 25 local branches. The Women's Hotline raised awareness about violence against women being a major social problem, making South Korean society realize that domestic violence was a crime, and played an important role in establishing laws for women's rights. The hotline works in various fields to protect women's rights including domestic violence, sexual violence, sex trade and trafficking of women, and migrant women's issues.

In addition to publicizing sexual and domestic violence, there were movements for human rights for working women, such as Alternative Culture (Clark 2000, 177). In the late 1980s, South Korean women workers made just over half of what men were paid in similar jobs. Through women's movement and civil society movements, female workers learned to negotiate with management for better wages and working conditions, basing their arguments on the Constitution and many laws that proclaim South Korea's commitment to gender equality and equal justice (Clark 2000). 
The pace of development of the women's movement escalated in tandem with the launch of women's organizations and their coalition-building from a clearly feminist viewpoint (O Jang 2004). In 1987, Korean Women's Association United, Korean Womenlink, and Korean Women Workers Association coalesced around the women's rights movement. Korean Women's Association United took the lead in the movement to establish laws for women's rights and played a key role in abolishing the hoju System (Korean Women's Association United website). Korean Womenlink worked to promote gender equality and participatory democratic society through social activities, campaign, media, and counseling (Korean Womenlink website). Korean Women Workers Association represented women workers to improve their economic, political and social status (Korean Women Workers Association website). Women's movements in civil society influenced not only public culture and mindsets of individuals, but also the policymaking process, and provided legal basis for gender equality and women's human rights.

\section{(2) Legal and Institutional Basis for Women's Empowerment}

Movements at the global level also had an impact on South Korea's domestic civil society movements for gender equality and women's rights. The International Women's Year of 1975 and the subsequent United Nations Decade for Women (1976-1985) brought about significant advancement for South Korean women. In particular, the adoption of the Convention of Elimination of All Forms of Discrimination against Women (CEDAW) by the United Nations General Assembly in 1979, with its worldwide impact on enhancing of the status of women, has greatly changed public attitude in South Korea towards gender equality (Paik 1998).

Starting with Ewha Womans University in 1977, women's studies was introduced in South Korea, first with a few courses, and then as a major/department, which provided the ideological foundation for women's movement and contributed to raising women's consciousness. In addition to women's studies, three government institutions were established in the 1980s-90s. Korean Women's Development Institute (KWDI) and the National Committee on Women's Policies were established in 1983. The former was created as a research center and think tank, and the latter was to represent women's issues in government ministries. The Presidential Commission on Women's Affairs was established in 1998, which later became the Ministry of Gender Equality and Family.

South Korea has enacted several legislations for gender equality. One of the major gender equality acts is the Women's Development Act (WDA) in 1995. The WDA was enacted to promote women's development and to ensure gender equality in all fields of politics, economy, society and culture. This Act is the legal foundation of women's policies, which embodies duties of central and local governments to realize gender equality in various policy fields. 
In 1999, the Gender Discrimination Prevention and Relief Act was introduced. It aims to prohibit gender-based discrimination in employment, education, access to goods/facilities/services, and to protect the rights and interests of those who have been subjected to discrimination. The Act defines gender-based discrimination as "all kinds of differentiation, exclusion, or restriction on the basis of gender without any reasonable causes when recognizing or possessing fundamental human freedoms and exercising rights in political, economical, social, cultural, and other fields of daily life" (Article 2). In 2001, the National Human Rights Commission Act was passed. It is to prohibit privilege, exclusion, or distinction in providing/using employment, education, training, goods, services, transportation, or facilities according to one's gender, religion, disability, age, social status, regional, national or ethnic origin, physical features, marital status, race, skin color, political ideology, criminal record, sexual orientation or history of diseases, pregnancy or delivery, and family status. The establishment of a legal basis for gender equality and women's rights has paved the way for a culture with gender sensitivity.

An administrative institution for women also emerged. First established in 2001, the Ministry of Gender Equality became the Ministry of Gender Equality and Family (MGEF) in 2005, expanding its jurisdiction to family and child-care policies. It attempted to merge with the Ministry of Health and Welfare in 2008 , but failed after a series of objections from various women's groups whose concern was that this move would dilute, rather than strengthen, the focus on women's issues and problems. After several more name changes, the MGEF settled in 2010 to take responsibility for policies for women, family, youth and children.

\section{(3) GEM, Gender Gap Ranking}

The UNDP spearheaded efforts within the UN on human development. It developed the Human Development Index (HDI), which was first introduced in the Human Development Report 1990 (UNDP 2009). HDI measures three basic aspects of development at the level of individuals with a sharper focus on how economic development should address the needs of people: (1) health, (2) knowledge, and (3) standard of living. Since 1995, the Human Development Report has started focusing on women, introducing gender-related development index (GDI) and gender empowerment measure (GEM). These two measures have been widely used to provide a clear comparative benchmark for all nations over time, and in particular how they fare in terms of providing basic opportunities for women in education and other capabilities versus how women's opportunities are actually realized in political and economic spheres (Ibid.). GDI measures the same indicators as the HDI, but with a special emphasis on gender inequality. GEM measures how women are actually represented both in the economic and the political arenas, and thus is a good indicator for their empowerment. Table 2 provides 
the UNDP's GDI and GEM ranks in 2007, along with the specific indicators for the latter.

Table 2. Gender Gap Ranking, GDI AND Gem (2007)

\begin{tabular}{|c|c|c|c|c|c|c|c|c|c|}
\hline \multirow[t]{2}{*}{ Country } & \multirow[t]{2}{*}{$\begin{array}{l}\text { HDI } \\
\text { rank } \\
(2007)\end{array}$} & \multicolumn{2}{|c|}{$\begin{array}{c}\text { Giender } \\
\text { Development } \\
\text { Index } \\
\text { (GD1) }\end{array}$} & \multicolumn{2}{|c|}{$\begin{array}{l}\text { Gender } \\
\text { Empowerment } \\
\text { Measure } \\
\text { (GEM) }\end{array}$} & \multirow{2}{*}{$\begin{array}{l}\text { Seats in } \\
\text { parliament } \\
\text { held by } \\
\text { women } \\
\text { (2008) } \\
\text { (\% of total) }\end{array}$} & \multirow{2}{*}{$\begin{array}{c}\text { Female } \\
\text { legislators. } \\
\text { senior } \\
\text { officials and } \\
\text { managers } \\
(1999-2007) \\
\text { (\% of total) }\end{array}$} & \multirow{2}{*}{$\begin{array}{c}\text { Female } \\
\text { professional } \\
\text { and } \\
\text { technical } \\
\text { workers } \\
(1999-2007) \\
\text { (\% of total) }\end{array}$} & \multirow{2}{*}{$\begin{array}{c}\text { Ratio of } \\
\text { estimated } \\
\text { female to } \\
\text { male earned } \\
\text { income } \\
(1996-2007)\end{array}$} \\
\hline & & Rank & Value & Rank & Value & & & & \\
\hline Australia & 2 & 1 & 0.966 & 7 & 0.870 & 30 & 37 & 57 & 0.70 \\
\hline Norway & 1 & 2 & 0.961 & 2 & 0.906 & 36 & 31 & 51 & 0.77 \\
\hline Iceland & 3 & 3 & 0.959 & 8 & 0.859 & 33 & 30 & 56 & 0.62 \\
\hline Canada & 4 & 4 & 0.959 & 12 & 0.830 & 25 & 37 & 56 & 0.65 \\
\hline Sweden & 7 & 5 & 0.956 & 1 & 0.904 & 47 & 32 & 51 & 0.67 \\
\hline France & 8 & 6 & 0.956 & 17 & 0.774 & 20 & 38 & 48 & 0.61 \\
\hline Netherlands & 6 & 7 & 6.95 .1 & $s$ & 0.882 & 39) & $2 \mathrm{x}$ & so & 0.67 \\
\hline Finland & 12 & 8 & 0.954 & 3 & 0.902 & 42 & 29 & 53 & 0.73 \\
\hline Spain & 15 & 9 & 0.949 & 11 & 0.835 & 34 & 32 & 49 & 0.52 \\
\hline Ireland & 5 & 10 & 0.948 & 22 & 0.722 & 15 & 31 & 53 & 0.56 \\
\hline Belgium & 17 & 11 & 0.948 & 6 & $0.8^{-1}$ & 36 & 32 & 49 & 0.62 \\
\hline Denmark & 16 & 12 & 0.947 & 4 & 0.896 & 38 & 28 & 52 & 0.74 \\
\hline Switzerland & 9 & 13 & 0.946 & 13 & 0.822 & 27 & 30 & 46 & 0.62 \\
\hline Japan & 10 & 14 & 0.945 & 57 & $0.56^{-}$ & 12 & 9 & -16 & 0.45 \\
\hline Italy & 18 & 15 & 0.9 .45 & 21 & $0.7+1$ & 20 & 34 & 47 & 0.49 \\
\hline Luxemhourg & 11 & 16 & 0.943 & $=$ & $\cdot$ & 23 & - & - & 0.57 \\
\hline $\begin{array}{l}\text { United } \\
\text { Kingdom }\end{array}$ & 21 & 17 & 0.943 & 15 & 0,790 & 20 & 34 & 47 & 0.67 \\
\hline New Zealand & 20 & 18 & 0.943 & 10 & $0.8+1$ & 34 & 40 & 54 & 0.69 \\
\hline United States & 13 & 19 & 0.942 & 18 & 0.767 & 17 & 43 & 56 & 0.62 \\
\hline Germany & 22 & 20 & 0.939 & 9 & 0.852 & 31 & 38 & 50 & 0.59 \\
\hline Greece & 25 & 21 & 0.936 & 28 & 0.677 & 15 & 28 & 49) & 0.51 \\
\hline Hong Kong & 24 & 22 & 0.934 & $*$ & $\ldots$ & $\therefore$ & 30 & 42 & 0.73 \\
\hline Austria & 14 & 23 & 0.930 & 20 & 0.744 & 27 & 27 & 48 & 0.40 \\
\hline Slovenia & 29 & 24 & 0.927 & 34 & 0.641 & 10 & 34 & 56 & 0.61 \\
\hline South Korea & 26 & 25 & 0.926 & 61 & 0.554 & 14 & 9 & 40 & 0.52 \\
\hline
\end{tabular}

SOURCE: UNDP.

South Korea's GEM is at rank 61, far below its GDI at 25, suggesting that South Korea has its own challenges to improve gender equality. Some have 
used this to argue that it may be premature for South Korea to engage in gender-related ODA. South Korea is indeed a showcase, proving that improvements in women's education and employment opportunities do not automatically lead to their empowerment. Nonetheless, it should not be used as an excuse for preventing South Korea from promoting gender-related ODA. If anything, the lessons it has learned over the course of development need to be shared with other developing countries in poverty, that women's education and employment are critically important for development; and that women's empowerment should be addressed concomitantly with women's employment.

\section{Gender Equality and Gender Mainstreaming in South Korea's Foreign Aid}

\section{Global Governance on Gender in Aid}

At the United Nations Fourth World Conference on Women held in Beijing in 1995, the OECD/DAC members and their partner countries made commitments to gender equality and women's empowerment. The Beijung Deckation and Platform for Action adopted at the Conference are based on the perspectives outlined at previous UN conferences on gender including the Convention on the Elimination of All Forms of Discrimination against Women (CEDAW) in 1979 (OECD 1999). It recognizes that gender equality and women's empowerment are essential for addressing global poverty and insecurity challenges, and for achieving sustainable development,

There appears to have been a paradigm shift in the way in which women are viewed in development. First, the "Women in Development (WID)" approach became prominent in North America in the 1970s with an emphasis on engaging women in the development process (Reeves and Baden 2000). The policies and programs focused on creating employment and income-generating opportunities for women, and improving access to education and credit (Ibid.). However, this approach came under attack as it was considered insufficient to address the broader underlying social inequality between genders, and thus the "Gender and Development (GAD)" approach became a new paradigm (Ibid.). This approach takes up where WID left, in terms of trying to address the key cause that had initially led to a lower participation rate of women in the labor force and lower pay for women vis-à-vis men. GAD stresses that WID measures cannot work unless the underlying structure of gender inequality and power relations changes. Thus, GAD is broader than WID, going beyond economic issues to touch on social power relations. This paper will utilize the lessons learned from GAD to provide recommendations that not only address women's economic participation in economic development, but also to redress the inequality women 
face in developing nations through ODA.

The Millennium Development Goals (MDGs)' Goal 3 includes gender equality as one of the most important goals to reduce poverty. It promotes gender equality and women's empowerment and suggests that donors provide aid with the goal to help eliminate gender disparity in primary and secondary schools (UN 2010). The 2007 G8 Summit in Heiligendamm, Germany recognized gender equality as a core principle for development policy and reaffirmed the importance of political and economic empowerment of women as a key contribution to sustainable growth and responsible government. It also underlined the importance of education as well as health issues, and pledged to take concrete steps to ensure that greater attention and resources are allocated to HIV/AIDS prevention, treatment and care to address the needs of women and girls (OECD 2007).

\section{2. $O E C D / D A C$ Guidelines}

The OECD/DAC High Level Mceting held in 1995 endorsed gender equality as a central goal for development and development cooperation efforts (OECD 1999). Reflecting changes in the priorities and mechanisms of development cooperation for gender equality, OECD/DAC published policy guidelines for gender equality and women's empowerment in development cooperation. Highlights in the guidelines include:

- a shift in emphasis from women as a target to gender equality as a development objective;

- an emphasis on mainstreaming to influence policy formulation, methodologies for planning and evaluation, institutional structures and decision-making procedures;

- an emphasis on the supportive role of DAC members in facilitating change through development partnerships, in particular through advocating for the implementation of international agreements (OECD 1999).

The commitments in the Beijing Platform for Action (1995) and the goals endorsed by the 1995 DAC High Level Meeting highlight that "the pursuit of gender equality is not a sector for separate attention, but a broad cross-cutting concern that involves all sectors" (OECD 1999). In this spirit, the OECD/DAC recognizes that gender mainstreaming is a vital tool for the promotion of gender equality and suggests that member countries ensure the mainstreaming of gender equality in their own processes (OECD 1999).

In addition, OECD/DAC focuses on women's empowerment for achieving gender equality. OECD/DAC stresses the importance of building gender-sensitive economic governance and institutional mechanisms for women's land and property rights as a key element to promote women's economic empowerment (OECD 1997; 2007). As an important cool for gender-sensitive economic governance, gen- 
der-sensitive budgeting has been suggested. In order to ensure better access of women to trade and investment, OECD/DAC recommends donors to promote investments in manufacturing and open markets particularly for products with important relevance for female labor, and to provide training for women's associations.

\section{South Korea's ODA for Gender Equality}

South Korea contributed a total of USD 816 million for international development assistance in 2009 (OECD 2010), and has pledged to expand its ODA volume to about USD 3 billion, and ODA/GNI to $0.25 \%$ by the year 2015 . However, only a small share of this budget is allocated to gender equality programs. In 2008, the Korea International Cooperation Agency (KOICA) spent only USD 2 million of its total budget (or $0.7 .4 \%$ of its total) for gender equality. If we recalculate the budget to include both cross-curting issucs of environment and gender programs, KOICA spent around USD 9 million in 2008, which is $3 \%$ of the total sectoral ODA expenditure (KOICA 2009). Lack of a strong focus on gender-related issues in ODA and data limitations have contributed to such low figures for ODA disbursement on gender (KWDI 2008). For example, KOICA's "Women Empowerment Programs in the Dominican Republic" (2007) was the only one considered to be a gender-specialized program, while all the other gender-related programs were in the form of education and training. This example shows that not only does South Korea suffer from lack of commitment toward gender equality as a cross-cutting issue, but also that there may be lapses in monitoring, which result in under-reporting of gender related ODA expenditures. In either case, there has to be a sharper focus on gender both at the policy goal level and at the implementation and monitoring levels.

When South Korea was planning to join the OECD/DAC, it requested a Special Peer Review of South Korea in 2008. Among other things, the report recommended South Korea to focus more on cross-cutting issues including gender equality, to develop gender-responsive programs, and to increase budget allocation in gender-related programs (OECD 2008). Thus, the South Korean government began to promote gender interests in ODA, and worked hard to pass the Basic Law on International Development Cooperation at the National Assembly in November 2009. The law included a clause that South Korea's ODA should provide aid for women and children and achieve gender equality throughout all aid programs.

However, resources for gender equality are still insufficient to promote gender mainstreaming (KWDI 2008). First, most of the gender related programs are focused on education and health, allowing only limited gender-oriented support for agriculture and the private sector. Second, there is a huge gap between policy and implementation for gender equality, in addition to lack of human 
resources and budget allocation. In 2010, for example, KOICA created a team of gender specialists in charge of promoting gender-responsive aid programs in South Korea's development assistance; also among its responsibilities are participation in the OECD/DAC Network on Gender Equality (GENDERNET) and training of KOICA employees and ODA partners (Sul 2010). However, it is a tall order for a relatively small, junior team to carry out all these tasks. Thus, KOICA should develop an institutional mechanism to promote gender equality throughout the whole ODA implementation system.

The aforementioned institutions for domestic gender equality, such as the Ministry of Gender Equality and Family (MGEF) and Korean Women's Development Institute (KWDI), have also contributed to the promotion of gender-responsive aid programs in developing countries. The MGEF has been implementing ODA programs for women since 2003. It has provided IT Training Programs for women in APEC countries, which will be expanded to local areas in the region. KWDI has been conducting research on gender related ODA issues. It would be important to provide more support for these institutions in order to help promote gender-responsive aid programs. gender-related research and to develop gender-focused policies for developing countries (Kim 2009).

Gender is an important macroeconomic variable and gender relations can affect economic development and growth (Seguino 2000). As recommended by the OECD/DAC in its Special Review of South Korea in 2008 and based on what South Korea itself went through in its own economic development, it would be important to strengthen South Korea's commitment toward gender in ODA. The following areas of emphases are what South Korea should do in such activities given the South Korean experience and OECD/DAC guidelines on gender:

- Implementation of affirmative action to increase women's participation through institutional improvement

- Integration of the gender perspective into law, policy and budget

- Raising consciousness of gender equality throughout society

\section{CONCLUDING REMARKS}

This paper examined Souch Korea's experience in economic development from a gender perspective. The employment of women in the light manufacturing export sector provided the first basis for its rapid development. While women's employment did not immediately lead to women's empowerment, active civil society movements and concerted efforts made gradual improvements in women's status. Still, this remains an on-going challenge for South Korea.

Since joining the OECD/DAC, South Korea has been advised to pay more attention to cross-cutting issues of gender and environment in its foreign aid. Combining South Korea's own experiences of gender in development and the 
OECD/DAC's recommendations, we have identified the ways in which South Korea needs to move forward with its emphasis on gender in ODA.

The paper's main findings and recommendations are summarized as follows: First, in many less developed countries with large numbers of women employed in the light manufacturing labor-intensive industries, women's low wages, low skills and gender wage gap remain a challenge. Second, since giving women low-paying jobs may not automatically lead to women's empowerment, there should be concerted efforts to improve women's wage and skill levels, and reduce the gender wage gap. Third, when ODA is provided to such nations, there has to be greater sensitivity to address gender-related issues in order to help women attain economic as well as political empowerment. Gender-mainstreaming, gender-sensitive budgets and other OECD/DAC guidelines should be taken into consideration in ODA. These include: (1) gender-mainstreaming in all aspects of ODA, (2) gender-sensitive industrial policy, (3) gender-sensitive budget, (4) institutional, legal mechanism to guarantee women better access to education and training, and (5) support international as well as domestic civil society organizations to work together for women's empowerment. Finally, women's empowerment still leaves much to be desired in South Koreat even though it has become a donor of ODA. South Korea has still much to improve in women's employment and empowerment both in domestic policies and in ODA programs.

The recent global financial crisis (2008-) has shown once again that women are the most vulnerable group that suffers disproportionately during times of crisis. Women were the first to be fired, forced to move from formal to informal sector jobs, and their household and family care responsibilities increased. Thus, it is imperative that women be empowered so that they do not fall victim again in the face of future crises that may be financial or otherwise. And, ODA to developing countries and to extreme poverty countries must address this issue since women in these countries may have even less political power and economic resources. South Korea's experience of its economic development with women at the core of its industrialization and strong efforts to improve women's rights should be relevant and in line with OECD/DAC guidelines on gender equality. Thus, we need to study the South Korean case of gender equality in development since it provides more relevant experiences as well as challenges for gender empowerment for other developing countries. than more advanced industrial nations that have better gender equality.

\section{REFERENCES}

Amsden, Alice. 1989. Asia's Next Giant: South Korea and Late Industrialization.

London: Oxford University Press.

Berik, Gunseli. 2006. Growth with Gender Inequality: Another Look at East 
Asian Development. University of Utah, Department of Economics Working Paper No. 2006-03.

Clark, Donald N. 2000. Culture and Customs of Korea. Westport: Greenwood Press.

Constitutional Court of Korea. 2005. Case on the House Head System. Online at: http://english.ccourt.go.kr/, accessed on Oct. 14, 2010.

Goldin, Claudia Dale. 1990. Understanding the Gender Gap. New York: Oxford University Press.

Kendall, Laurel (ed.). 2002. Under Construction: The Gendering of Modernity. Class, and Consumption in the Republic of Korea. Honolulu: University of Hawaii Press.

Kim, Eun Mee. 1997. Big Business. Strong State: Collusion and Conflict in South Korean Development 1960-1990. New York: State University of New York Press.

Kim, Seung-kyung. 1997. Class Struggle or Family Struggle?: The Lives of Women Factory Workers in South Korea. Cambridge: Cambridge University Press.

KOICA. 2009. 2008 KOICA Aid Statistios. Seoul: Korea International Cooperation Agency.

Koo, Hagen. 2001. Kowsm Workers: The Culture and Politis of Class Formation. Ithaca, NY: Cornell University Press.

Korean Women Workers Association. 2010. Online at: http://kwwatistory.com/ category/WHO\%20WE\% 20ARE/Herstory, accessed on Oct. 11.

Korea Women's Association United. 2010. Online at: hetp://www.women21.or.kr/ english/:pid=english\&'sid $=$, accessed on Oct. 11 .

Korea Women's Hot Line. Online at: http://eng.hotlinc.or.kr/aboutus.php, accessed on Oct. 11, 2010.

Korea Womenlink. 2010. Online at: http://www.womenlink.or.kr/eng/eng_intro.php, accessed on Oct. 11.

Korea Women's Development Institute. 2008. Gender Analysis of Korea ODA. Seoul: Korea Women's Development Institute.

Ministry of Employment and Labor. 2010. Online at: http://125.60.1.57:8080/file _root $/$ media/0/150/media/default 1 ht $\mathrm{ml}$, accessed on Oct. 14.

OECD. 2010. Aid in Support of Gender Equality and Women's Empouerment. Paris: OECD.

2008. Special Review on Korea's Development Cooperation. Paris: OECD. 2007. Gender and Economic Empowerment of Women. Briefing Paper No. 3. Paris: OECD.

2001. Poverty-Environment Gender Linkages. Development Assistance Committee Journal 2(4): 1-91.

1999. DAC Guidelines for Gender Equality and Women's Empowerment in Development Cooperation. Paris: OECD.

1998. DAC Source Book on Concepts and Approaches Linked to Gender Equality. Paris: OECD. 
O Jang, Mi-Kyung. 2004. Women's Movement and Participation in Public Policy (from 1987 to the present). Civil Society and NGO 2(1): 201-310.

Paik, Young-Joo. 1998. Women's Development and Information on Women in Korea. Paper presented at $64^{\text {th }}$ IFLA General Conference (August. 16-21), 1998. Korea.

Reeves, Hazel and Sally Baden. 2000. Gender and Development: Concepts and Definitions. BRIDGE Report No. 55. Brighton: Institute of Development Studies.

Sachs, Jeffrey D. 2005. The End of Poverty. New York: Penguin Press.

Seguino, Stephanie. 2000. Gender Inequality and Economic Growth: A CrossCountry Analysis. World Development 28(7): 1211-1230.

1997. Gender Wage Inequality and Export-Led Growth in South Korea. The Journal of Development Studies 34(2): 102-132.

Sen, Amartya. 1999. Development as Freedom. Oxford: Oxford University Press.

Standing, Guy. 1999. Global Feminization through Flexible Labor: A Theme Revisited. World Development 27(3): 583-602.

Turner, Charlie and Elizabeth Monk-Turner. 2007. Gender Differences in Occupational Status in the South Korean Labor Market: 1988-1998. International Joumal of Soctal Economics 34(8): 554-565.

Tzannatos, Zafiris, 1998. Women and Labor Market Changes in the Global Economy: Growth Helps, Inequalities Hurt and Public Policy Matters, World Bank Social Protection Discussion Paper No. 9808, Washington: World Bank. UN. 2010. Millennium Development Goals Report. New York: United Nations. UNDP. 2009. Human Development Repart. New York: United Nations Development Programme.

Wade, Robert. 1990. Governing the Market: Economic Theory and the Role of Government in Taiwan's Industrialization. Princeton: Princeton University Press.

Woo, Jung-en. 1991. Race to the Swift: State and Finance in Korean Industrialization. New York: Columbia University Press. 